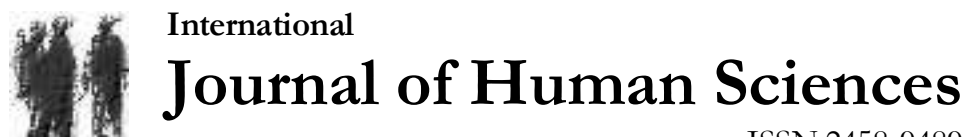 \\ ISSN:2458-9489
}

Volume 15 Issue 3 Year: 2018

\section{A review of doctoral dissertations in architecture in Turkey}

\author{
Yasemin Erbil ${ }^{1}$ \\ Miray Gür ${ }^{2}$
}

\begin{abstract}
The social and scientific importance of doctoral dissertations have increased in the context of Mission Differentiation and Specialization Project in Turkey and potential doctoral studies should be carefully conducted with the aim of contribution to community development, policies, science and practice area through the envisaged research fields. The purpose of this study is to examine doctoral dissertations in architecture in the academic literature within the scope of Thesis Center of the Council of Higher Education and to reveal the researchers' profile with a view to contributing to the evolving research agenda in Turkey. For this purpose quantitative analyses of doctoral dissertations in Architecture in Turkey is made. The universe of the study constitutes 1170 doctoral dissertations completed between 1990-2018, which are archived in the database of the Thesis Center of the Council of Higher Education and indexed under the subject architecture. All of the doctoral dissertations included in the sample were analyzed using various standards such as the years they were completed, the language they were written in, the university they were completed in, the gender of the author, and the advisor's title. The collected data was analyzed with descriptive statistical methods. According to the results, it was found out that the highest number of dissertations produced was in the architectural design discipline, by mostly female researchers, with dissertation supervisors who were mostly professors, while Turkish was the most used language and Istanbul Technical University was the institution where most of the dissertations were produced. The results coming out of this study will be helpful to the increase of research activities in the field of architecture in Turkey, to train researchers in universities in required fields, to direct scientific research in the right way and to contribute to the vision setting activities of universities.
\end{abstract}

Keywords: $\mathrm{PhD}$ in architecture; research work; research universities; quantitative assessment; architectural education; doctoral dissertation]

\section{Introduction}

Architecture is the discovery and design of the "new", and the identification and rejection of the present to reveal and invent the "other". Architecture aims to create original, innovative and valuable products and / or to address architectural thought and cultural context acceptable to society. Architecture as a discipline and a profession can clearly benefit from doctoral research because of the positive impact of established standards, funding, and global connections it provides (Illesanmi, 2016).

1 Assoc. Prof. Ph.D., Uludag University, Faculty of Architecture, erbil.yasemin@gmail.com

2 Asist. Prof. Ph.D., Uludag University, Faculty of Architecture, miraygur@yahoo.com 
Ph.D. research in architecture is about the development of innovative ideas and is important because of its social impact. Similar to other doctoral programs the doctoral education in architecture is about producing new knowledge and experiences. It is important that new and original products emerge from doctoral research and put forward to support future social development. Quality assurance is a part of the "production" process established by academic supervision that inspects the process and guarantees the validity of the result. This is a process, which can be called "a toolset" that assumes there is an acceptable and accredited infrastructure in which the norms and methods for research are defined, directed, inspected and accepted. Innovation in doctoral research is a condition expressed with the term "authenticity" (Voyatzaki, 2014). In this framework, architecture and doctoral research support each other because both seek designing, discovering and pursuing novelty. Research reveals new models in which the role of the architect is defined and activated, by defining the current situation in order to create healthier and pleasing relations between people and their surroundings.

Researchers conducting doctoral studies in design should specialize in the way that they will overcome of certain tasks, and research should focus on a number of areas to ensure this specialization. Contribution of doctoral studies that have different aims to the field of literature and practice can be diversified as; development of recommendations for functional and spatial programming, improving the quality of people's life environment through improving and modernizing standards, production of implications in the field of design and application in the direction of material, method, product or goals, linking decision-making process and education through research on design and expression methods such as digital modeling and digital computation, developing innovative ideas for design and implementation (Niezabitowska 2016, Dybczyńska-Bułyszko 2016, Ridolfi and Saberi 2016). The doctoral work in the field of design should improve recommendations by exploring the deficiencies, contribute to the transformation of the practice area and develop better approaches in this field. In this framework, relations between other practices and disciplines should be established in the doctoral work in design area (Margolin 2010). In line with the results of the research in literature, it is seen that the doctoral dissertations should not only be at the theoretical level and are expected to lead to discussions that can be reflected to practice area through their results. Research devoted to develop solution proposals for problematic areas in practice or policies will contribute to the science and practice. The social importance of doctoral dissertations have increased in the context of Mission Differentiation and Specialization Project that is initiated by Council of Higher Education in Turkey and production of qualified information, exploration of the "innovative" and "new", contribution to world science and development of the country have become the responsibilities of the universities in this framework. In this direction potential doctoral studies should be carefully directed and conducted with the aim of contribution to community development, policies, science and practice area and the human and pecuniary resource should be transferred to envisaged research areas.

Through the paradigm shift that has occurred lately concerning education and its components, new perspective of doctoral education put emphasis on individual qualities and aims of the PhD student as an indepent researcher (Sağlamer and Erkök 2015). Alongside the individual researcher tendencies, with the perspective of government policies directing research universities to focus on research development, the current situation needs to be analyzed in order to train researchers in the research areas in line with the requirements. In this context the aim of the study is to determine the current situation with the perspective of distribution of dissertations between different fields, universities, supervisors, languages and universities through quantitative analyses and to reveal the researchers' profile with a view to contributing to the evolving research agenda in Turkey. As seen in literature review, quantitative assessments regarding doctoral education in architecture have been made in different countries, while the research concerning the aims, content and quality of $\mathrm{PhD}$ education has been developed theoretically in Turkey generally. The research problem is to evaluate the different parameters of doctoral education in architecture according to 
Erbil, Y., \& Gür, M. (2018). A review of doctoral dissertations in architecture in Turkey. Journal of Human Sciences, 15(3), 1481-1490. doi:10.14687/ihs.v15i3.5407

the database of the Thesis Center of the Council of Higher Education and produce implications through the results gained in accordance with the responsibilities that the research universities should undertake and data provision for both of the research agencies and researchers. Accordingly, it is aimed to reveal the research activities in parallel with the objectives of the Council of Higher Education and to be helpful in determining a strategical road map.

\section{Literature Review and Theoretical Framework}

There are different approaches in the literature regarding the ties between architecture and research. The types of research vary from scientific to artistic research. Determination of which research rules would be most suitable for architectural research is a separate issue. Various terminologies stand out in the discussions on the relationship between research and design, which are 'research in design', 'research for design' and 'research through design' (Erkök and Sağlamer, 2015). On a global scale researches in the field of architecture are interdisciplinary and different research problems, research design and methods have been developed. Examples of some subheadings in the field of architectural research are given below (Illesanmi, 2016);

- Climatic, thermal comfort and structural studies (dominant in 1950s)

- Social-behavioral issues, design methods, sustainability and energy conservation (a large field of study in 1960s and 1970s)

- History of architecture (art / aesthetics, theory and criticism and conservation in historical areas)

- $\quad$ Research on computer-aided design

- Research on building materials

- Research on housing, urban design, landscape architecture, interior architecture and specialized areas

Tools that support research are grouped into library resources, computers and software, measurement techniques, statistics, human intelligence and language (Leedy and Ormrod, 2010). The needs of institutional research infrastructures, qualifications of the faculty in research programmes, library resources, resources provided by funding models for design research, interdisciplinary research programs, balancing interdisciplinary challenges, evaluation of faculty and student research activities, and publishing or presenting research are important for increasing the quality of doctorate education in the field of architecture (Davis, 2008). In this context, physical facilities and equipment provided by universities and the number and quality of academic staff are important. The intensity of the undergraduate education and the course load of the instructors are also important factors that influence the time allocated to doctoral research.

When this issue is approached from the viewpoint of Turkey it can be seen that there are over one hundred architecture departments in state and private universities across the country. In the majority of these architecture departments the ratio of the number of academic staff to the number of students is not sufficient to ensure a high quality undergraduate and postgraduate education. In this framework, the doctorate programs in universities have an important role for creating the necessary academic output and to train researchers focusing on the field of architecture.

Within this framework, within the scope of "Mission Differentiation and Specialization Project" initiated by the Council of Higher Education some universities were given the title of research universities; among them 10 were designated as full members while 5 were designated as associate members. These research universities, which will aim to efficiently use the higher education infrastructure and human resources and to increase the international visibility, should serve the goals of and create strategic road maps for high quality data production, development of human resources with doctoral education, sharing and transferring the knowledge generated, creating expertise on the functioning of the research culture and methods, extending education programs with students taking part in research activities, producing research activities that create 

1481-1490. doi:10.14687/ihs.v15i3.5407

societal value and receive share from funds, contribute to the development of the world science, common values and development of the nation (http://yok.gov.tr). Separation of research universities in Turkey is an indication of increased importance given to doctoral education and the need to create new structures that create an orientation towers doctoral research in institutions.

In its current form the authority to open architectural doctoral programs in Turkey belongs to the Council of Higher Education (YOK). When a university wants to open a doctoral program, it has to prepare an application file based on the senate decisions and submit it to YOK. Programs only approved by YOK can begin. Architecture Ph.D. programs are programs that admit candidates with a Master's degree. During the first two years of the program, students take compulsory courses and elective courses that they determine in accordance with their fields and give seminars. After completion of the courses, students are subjected to a doctoral qualification examination. In the doctoral qualification examination, students are tested whether they have the depth of scientific research skills (on the dissertation topic) related to the basic subjects and concepts in their field and doctoral study. Following the successful completion of the examination, the dissertation development process starts together with the doctoral dissertation jury. Meetings are held twice a year with the jury. Finally, the students who complete their work defend their dissertation against the jury and receive the title of $\mathrm{PhD}$. $\mathrm{PhD}$ education is a process that is takes at least 4 years.

There are different researches in different countries that aim to direct studies and the propensity for the required areas in the future by examining the aims, achievements, areas and the percentages of dissertations in study fields and the demographical qualities of the researchers (Spiridonidis 2014, Gaston Guirao 2014, Illesanmi 2016, Mecca and Perrone 2014, Słyk et al. 2016, Harris et al. 2004). In Turkey there are studies concerning the aims, importance and development of $\mathrm{PhD}$ education in architecture but there are very few quantitative evaluations in this context conducted (Erkök and Sağlamer, 2011) and the studies are theoretically in Turkey generally (Yorgancioğlu 2014, Erkök and Sağlamer, 2015). For this reason, there is a gap in the literature in this regard and contribution to the field related to this study is aimed. Accordingly, through the purpose of the study, distribution of dissertations between different fields, universities, supervisors, languages and universities are analyzed with a quantitative approach and descriptive statistics. This article makes a quantitative assessment of doctoral dissertations, selected based on specific criteria, which were completed between the years 1990-2018 in Turkey in the field of architecture and archived by the Thesis Center of the Council of Higher Education in Turkey. By revealing the current situation and implications that are executed., it is aimed to help architectural institutions that have $\mathrm{PhD}$ programme and researchers in directing their study fields through required areas.

\section{Methodology}

$\mathrm{PhD}$ programs in architecture are a requirement for specializing in a particular subject and / or for making an academic career. Throughout the doctoral period, students are expected to design an academic research on a certain subject, submit their research in a systematic way and finding a solution to the problem they selected under the supervision of their supervisors and exchanging information with them. In this context, architectural doctorate programs are generally divided into Architectural Design, History of Architecture, Restoration, Structural Sciences categories. Within the scope of Ph.D. in Structural Sciences, research is being carried out in the fields of Building Physics, Building Elements, Building Materials, Carrier Systems, and Construction Management. According to the literature there are no analyses evaluating the doctoral dissertations in the field of Architecture at universities in Turkey and detecting the orientation of the issues studied in such thesis. Various studies suggest that quantitative data on the past of design research, research cultures, international positions of universities and research activities provide clear results (Davis 2008, Illesanmi 2016). The aim of this research is to establish a basis for future research in this field and to fill this gap in the literature. 
In this study, doctoral dissertations prepared in the field of architecture in Turkey were analyzed quantitatively by frequency analyses according to specified criteria. Document analysis method was used for this purpose. A total of 1315 doctoral dissertations with the subject of architecture were archived in the database of the Thesis Center of the Council of Higher Education. There are 1261 doctoral dissertations for the period 1990-2018. Among the dissertations, it was determined that some were related to different scientific fields than architecture. After these dissertations were excluded from the study, the remaining number of doctoral dissertations to be evaluated was 1170. Data collection began on January 30, 2018 and ended on February 22, 2018.

\section{Results}

$\mathrm{PhD}$ dissertations included in the sample group were examined in terms of their descriptive characteristics such as the language they were written, the university they were completed, the gender of the author, and the title of the advisor. The obtained data were analyzed by using descriptive statistics such as their percentage and frequency and the data was expressed in tables with numbers and percentages.

As shown in Table 1, the number of $\mathrm{PhD}$ dissertations in Architecture Departments completed between the years 1990-2018 in Turkey was 1170. The number of dissertations completed in the field of Construction Sciences was 321 (27.4\%), whereas it was $563(48.1 \%)$ in Architectural Design, 174 (14.9) in Restoration, and 112 (9.6\%) in Architectural History. It is seen that most of the doctorate dissertations was in the Architectural Design discipline. Design is a discipline that mediates relationships between people and the activities in relation with the environment. One of the reasons for the need for research in the field of design is that the research creates the properties of "laboratories" which separates the behaviors from the context in which they take place. The results of surveys of questioning people's actions are useful inputs that improves design (Davis, 2008).

Table 1. Distribution of dissertations by education departments

\begin{tabular}{|l|c|c|}
\hline Type of Dissertations & $\mathrm{f}$ & $\%$ \\
\hline Architectural design & 563 & 48.1 \\
\hline Structure Information & 321 & 27.4 \\
\hline Restoration & 174 & 14.9 \\
\hline Architecture History & 112 & 9.6 \\
\hline Total & 1170 & 100 \\
\hline
\end{tabular}

In Table 2, the distribution of the Architecture dissertations are given based on the universities they were completed. Ten universities with the greatest number of doctoral dissertations were included in the table. Accordingly it can be seen that $374(32 \%)$ doctoral dissertations were completed in Istanbul Technical University, $183(15 \%)$ in Yildı Technical University, 147 (12,6\%) in Middle East Technical University, and 87 (7. 4\%) in Mimar Sinan Fine Arts University. 
Erbil, Y., \& Gür, M. (2018). A review of doctoral dissertations in architecture in Turkey. Journal of Human Sciences, 15(3), 1481-1490. doi:10.14687/ihs.v15i3.5407

Table 2. Dissertations by universities

\begin{tabular}{|l|l|c|c|}
\hline \multicolumn{2}{|l|}{ Universities } & \multicolumn{2}{c|}{ Doctorate } \\
\cline { 3 - 4 } & Istanbul Technical University & f & $\%$ \\
\hline 2 & Yildiz Technical University & 183 & 32.0 \\
\hline 3. & Middle East Technical University & 147 & 15.6 \\
\hline 4 & Mimar Sinan Fine Arts University & 87 & 72.6 \\
\hline 5. & Gazi University & 79 & 6.4 \\
\hline 6 & Karadeniz Technical University & 78 & 6.7 \\
\hline 7 & 9 Eylül University & 59 & 5.0 \\
\hline 8 & Trakya University & 62 & 5.3 \\
\hline 9 & İzmir Higher Institute of Technology & 40 & 3.4 \\
\hline 10 & Selcuk University & 32 & 2.7 \\
\hline 11 & Other Universities & 29 & 2.5 \\
\hline & Total & 1170 & 100 \\
\hline
\end{tabular}

The distribution of dissertations studied is shown in Table 3. Accordingly, between the years 1990-1994 84 dissertations were produced (7.2\%), whereas the dissertations produced between 1995-1999 was 163 (13. 9\%), and 174 (14. 9\%) 2000-2004, 240 (20\%) between 2005-2005, $326(27.9 \%)$ between 2010-2014, $183(15.6 \%)$ between 2015-2018. Because the dissertations archived in the Thesis Center of the Council of Higher Education was used for the creation of the database, only the dissertations that were added to the archives before the end of 2018 February could be reached, which was 183 dissertations and accounts for $15.6 \%$.

Table 3. Distribution of dissertations by years of completion

\begin{tabular}{|l|c|c|}
\hline \multirow{2}{*}{ Year } & \multicolumn{2}{|c|}{ Doctorate } \\
\cline { 2 - 3 } & $\mathrm{f}$ & $\%$ \\
\hline $1990-1994$ & 84 & 7.2 \\
\hline $1995-1999$ & 163 & 13.9 \\
\hline $2000-2004$ & 174 & 14.9 \\
\hline $2005-2009$ & 240 & 20.5 \\
\hline $2010-2014$ & 326 & 27.9 \\
\hline $2015-2018$ & 183 & 15.6 \\
\hline Total & 1170 & 100 \\
\hline
\end{tabular}

The distribution of dissertations by the language is shown in Table 4. Accordingly, in Turkey the number of dissertations completed in the Turkish was 911 with a rate of $77.9 \%$, while the number of dissertations prepared in English was 258 with a rate of $22.1 \%$, while the only dissertation prepared in German constitutes a rate of $0.1 \%$.

Table 4. Distribution of dissertations according to their language

\begin{tabular}{|l|c|c|}
\hline \multirow{2}{*}{ Languages } & \multicolumn{2}{|c|}{ Doctorate } \\
\cline { 2 - 3 } & $\mathrm{f}$ & $\%$ \\
\hline Turkish & 911 & 77.9 \\
\hline English & 258 & 22.1 \\
\hline German & 1 & 0.1 \\
\hline Total & 1170 & 100 \\
\hline
\end{tabular}


Erbil, Y., \& Gür, M. (2018). A review of doctoral dissertations in architecture in Turkey. Journal of Human Sciences, 15(3), 1481-1490. doi:10.14687/ihs.v15i3.5407

Table 5 shows the distributions of doctoral studies in the field of architecture according to the titles of their supervisors. Of the faculty members who supervised doctoral researches, 838 (71.6\%) were professors, $235(20.1 \%)$ were associate professors, and $97(8.3 \%)$ were assistant professors.

Table 5. Distribution of titles of dissertations supervisors

\begin{tabular}{|l|c|c|}
\hline \multirow{2}{*}{ Title of Dissertations Supervisors } & \multicolumn{2}{|c|}{ Doctorate } \\
\cline { 2 - 3 } & $\mathrm{f}$ & $\%$ \\
\hline Professor & 838 & 71.6 \\
\hline Associate Professor & 235 & 20.1 \\
\hline Assistant Professor & 97 & 8.3 \\
\hline Total & 1170 & 100 \\
\hline
\end{tabular}

Table 6 shows the gender of researchers who have completed doctorate dissertations in the field of architecture. Accordingly, it was seen that the number of female researchers was 762 $(65.1 \%)$ and the number of male researchers was 408 (34.9\%).

Table 6. Distribution of dissertations by gender

\begin{tabular}{|l|c|c|}
\hline \multirow{2}{*}{ Gender } & \multicolumn{2}{|c|}{ Doctorate } \\
\cline { 2 - 3 } & $\mathrm{f}$ & $\%$ \\
\hline Females & 762 & 65.1 \\
\hline Males & 408 & 34.9 \\
\hline Total & 1170 & 100 \\
\hline
\end{tabular}

\section{Discussion and Conclusion}

In this study, 1170 doctoral dissertations archived in the database of YOK, in the field of Architecture completed between the years 1990-2018 were evaluated. In this context, when the distribution of the dissertations according to their fields is examined; it is seen that most of doctorate research is done in the field of architectural design. The field of building science was the second area with the highest number of dissertations, and the field of architecture history was the least preferred field for doctoral dissertations. Rouillard (2014) emphasizes the importance of doctorate dissertations in the field of architecture by being more holistic, that all architectural formations and professional influences are interesting, and that doctorate dissertations should contribute to the consolidation and renewal of knowledge, which in turn can mobilize its own environment. The decision of the researcher for the field to be studied is important, and the researcher should work in field that he/she wants to concentrate on, and to understand and produce solutions. According to the results obtained by Illesanmi (2016), the field of the supervisor is effective in the selection of the subject to be studied in the doctoral researches. In addition to this, factors such as the extensive data in housing research, the broader and more accessible literature, the fluidity of architectural knowledge base, and the ability of the subject area to assume the contextual or basic research identity are influential in the selection of the research topics (Illesanmi, 2016). Based on observations it is also possible to say the same for Turkey. Researchers have difficulty in narrowing their study fields until they are fully focused on a specific target, and may require the assistance of their supervisor for directions. It is also seen that doctorate studies are carried out in order to produce solutions to the problems of the country and academic fields are also shaped in this direction. In a study in Italy, it was seen that doctorate programs to protect architectural heritage use a broad perspective in order to contribute to the society (Franco, 2014). In this context of doctoral studies in Turkey (for example in the fields of urban renewal, construction technologies, green buildings) are carried out for the development of the country. 
Erbil, Y., \& Gür, M. (2018). A review of doctoral dissertations in architecture in Turkey. Journal of Human Sciences, 15(3), 1481-1490. doi:10.14687/ihs.v15i3.5407

Determination of subjects of doctoral research that can produce solutions to physical, social or economic problems has a high potential for social benefit. Following the decision of the researcher on the field of research, the decision to complete the research in which university can be effected by the city that the researcher lives in, his/her employment, and university criteria. In Turkey it was seen that most doctoral dissertations were completed at the Technical University of Istanbul, which is followed by Yildiz Technical University, Middle East Technical University and Mimar Sinan Fine Arts University. In universities the reason for a lower number of completed dissertations can be explained by several factors such as whether the university is well-established, the workload of faculty members due to courses, physical facilities and the number of academic staff. While well-established universities have been carrying out doctoral studies with a larger number of faculty members, newly established universities have to overcome problems such as creating systems, lack of academic personnel and other workloads due to courses.

It is seen that among the academic members who supervise doctoral dissertations at universities, the highest ratio was supervisors with the title of professor, and the lowest ratio was supervisors with the title of assistant professor. Assistant associate professors focusing on undergraduate education, and more experienced academia focusing more on postgraduate education are among the reasons. It is also expected that the academicians will need to fulfill criteria that universities set for supervising doctoral dissertations.

Most of the doctoral dissertations in Turkey were completed between 2010-2014, while the period of 1990-1994 produced the least amount of doctoral dissertations. For the determination of the number of dissertations completed between 2015 and 2018, only those completed before the of February 2018 were taken into consideration and it is anticipated that the rate for this period will be more than $30 \%$ by the end of 2019 , when the number of dissertations completed between these years are considered. The number of dissertations in Turkey is increasing every year in parallel to the increase of researchers, and the increase of the number of doctoral education institutions and programs.

When the languages of dissertations are considered, it can be seen that the most used language in doctoral dissertations is Turkish, followed by English. In line with the internationalization strategies of $\mathrm{YOK}$, it can be predicted that the number of doctorate dissertations that will be prepared in English will increase in the coming years.

In the analysis, it was seen that the number of female researchers that made doctoral research is higher. This shows that despite the sexual discrimination faced by women in many areas of the Turkish society, they tend to become more influential in the scientific life.

As a result, it is seen that in Turkey especially in the last 10-15 years there was a significant increase in the number of universities, however the increase in the number of academic staff was not in parallel. However, the results of the research show that the increase in the number of doctoral dissertations in the following years will make it possible to overcome this issue. On the other hand, in line with the internationalization strategies and the goals of the research universities in the country, efforts are being made to provide solid added value to the scientific community in the world, society and architecture profession, by creating interdisciplinary knowledge, sharing and transferring the knowledge created. In this context it is expected that this research will to contribute to the increase of research activities in the field of architecture in Turkey, to train researchers in universities in necessary fields, to direct scientific research in the right way and to contribute to the vision setting activities of universities. This research is a pioneering work and hopes to create a more comprehensive research infrastructure. In the course of the research, it is possible to examine the research methods used in doctoral dissertations according to the research areas. 
Erbil, Y., \& Gür, M. (2018). A review of doctoral dissertations in architecture in Turkey. Journal of Human Sciences, 15(3), 1481-1490. doi:10.14687/ihs.v15i3.5407

\section{References}

Davis, M. (2008). Why do we need doctoral study in design?, International Journal of Design 2 (3), 71 79

Dybczyńska-Bułyszko A. (2016). Design as method. Education for Research, Research for Creativity (Ed. Jan Slyk and Lia Bezerra), Wydział Architektury Politechniki Warszawskiej, 49-55

Erkök, F., \& Sağlamer, G. (2011). Doctoral studies in architecture, Fourth EUA-CDE Annual Meeting 2011 Promoting Creativity - cultivating the research mindset, 9-10 June 2011, Carlos III University of Madrid, Spain. Retrieved from: http://www.eua.be/Libraries/4th-eua-cde-ammadrid/4th_CDE_A_M_Plenary_3_Saglamer.pdf?sfvrsn=0

Erkök, F., \& Sağlamer, G. (2015). Forming a discussion platform for doctoral education in architecture. Doctoral Education in Architecture: Challenges and Opportunities in Architecture. (Ed. Sağlamer, G., Erkök, F.) Newcastle upon Tyne, England: Cambridge Scholars Publishing, 6-30

Franco, G. (2014). An interdisciplinary and inter-university doctoral experience in "Preservation of the architectural heritage", Doctoral education in schools of architecture across Europe (Ed. Voyatraki, M.) European Network of Heads of Schools of Architecture, 220-231

Gaston Guirao C. (2014). Doctoral studies in the Barcelona School of Architecture. Doctoral education in schools of architecture across Europe (Ed. Voyatraki, M.) European Network of Heads of Schools of Architecture, 363-376

Harris R., Giard J., \& Pijawka A. (2004). Interdisciplinary doctoral education in environmental design: assessment of programs, 1ssues, structure, and vision. Proceedings of the third conference Doctoral Education in Design, 14-17 October 2003, Tsukuba, Japan

Ilesanmi, A.O. (2016). Doctoral research on architecture in Nigeria: Exploring domains, extending boundaries. Frontiers of Architectural Research. 5(1), 134-142 (doi: 10.1016/j.foar.2016.01.002)

Leedy, P. D., \& Ormrod, J. E. (2010). Practical research: Planning and design (10th Edition), Pearson Education Limited.

Margolin V. (2010). Doctoral education in design: Problems and prospects. Design Issues, 26 (3), 70-78

Mecca S., \& Perrone C. ( 2014). Archidoctor Universalis. Doctorate in architecture at the University of Florence. . Doctoral education in schools of architecture across Europe (Ed. Voyatzaki, M.) European Network of Heads of Schools of Architecture, 207-218

Niezabitowska E. D. (2016). Post-occupancy evaluation methodology and its significance in relation to research by design. Education for Research, Research for Creativity (Ed. Jan Styk and Lia Bezerra), Wydział Architektury Politechniki Warszawskiej, 23-29.

Ridolfi G., \& Saberi A. (2016). Learning design through designerly thinking. Holistic digital modeling in a graduate program in architecture. Education for Research, Research for Creativity (Ed. Jan Styk and Lia Bezerra), Wydział Architektury Politechniki Warszawskiej, 62-67

Rouillard, D. (2014). For a doctorate in architecture. Doctoral education in schools of architecture across Europe. (Ed. Voyatzaki, M.) European Network of Heads of Schools of Architecture, 172178

Sağlamer, G., \& Erkök, F. (2015). Introduction. Doctoral Education in Architecture: Challenges and Opportunities in Architecture. (Ed. Sağlamer, G., Erkök, F.) Newcastle upon Tyne, England: Cambridge Scholars Publishing, 1-4

Słyk J., Koszewski K., Ostrowska K. \& Bezerra L. M. D. (2016). Developing a new PhD curriculum for an English-speaking doctoral course at the Architecture for the society of knowledge program, Faculty of Architecture, Warsaw University of Technology. Education for Research, Research for Creativity (Ed. Jan Slyk and Lia Bezerra), Wydział Architektury Politechniki Warszawskiej, 23-29. 
Spiridonidis C. ( 2014). Practising architectural research, researching architectural practice. Doctoral research in the School of Architecture of Aristotle University of Thessaloniki. Doctoral education in schools of architecture across Europe (Ed. Voyatzaki, M.) European Network of Heads of Schools of Architecture, 191-206

Voyatzaki M. (2014). (Ad)ventures of doctoral research in architecture: Attachment, autonomy, ambivalence. Doctoral education in schools of architecture across Europe. (Ed. Voyatraki, M.) European Network of Heads of Schools of Architecture, 20-29

Yorgancioğlu D. (2014). The growing significance of research as part of architectural education and the doctoral programmes in architecture. Doctoral education in schools of architecture across Europe (Ed. Voyatzaki, M.) European Network of Heads of Schools of Architecture, 414-436

Yükseköğretim Kurulu Başkanlığ1, Ulusal Tez Merkezi, https://tez.yok.gov.tr/UlusalTezMerkezi/giris.jsp, Access Date: January 2018

Yükseköğretim Kurulu Başkanlığı, Meeting with "Research and Candidate Research Universities" http://yok.gov.tr/web/guest/icerik/-

/journal_content/56_INSTANCE_rEHF8BIsfYRx/10279/38141373, Access Date: May 2018 